\title{
Analysis of Liquid Phase Mass Transfer at Free Surface in Gas-stirred Vessel
}

\author{
Hirotada Arai ${ }^{1)^{*}}$ and Katsutoshi MAtsumoto ${ }^{1)}$
}

1) Department of Material and Biological Engineering, National Institute of Technology, Hachinohe College

Abstract: Gas injection has been widely used to enhance mass transfer and homogenization of temperature and composition of molten steel. In this paper, water model experiments for degassing were performed to investigate mass transfer at free surface in a gas-stirred vessel. Mass transfer coefficients in liquid phase were measured and the correlation with gas flow rate and liquid height were analyzed. A mass transfer model was constructed based on the Levich's model assuming that a part of energy input by gas injection was consumed near the free surface. As a result, the following dimensionless correlation was obtained:

$$
\mathrm{Sh}=23\left[\frac{d^{2}}{v} \frac{\rho(h v \epsilon / d)^{3 / 4}}{\sigma}\right]^{1 / 2} \mathrm{Sc}^{1 / 2}
$$

The present correlation agrees well with the mass transfer coefficients in liquid phase including previous data for water model systems and that of molten steel systems can be also approximately estimated.

Keywords: gas-liquid mass transfer; mass transfer coefficient; free surface; mass transfer model; gas-stirred vessel.

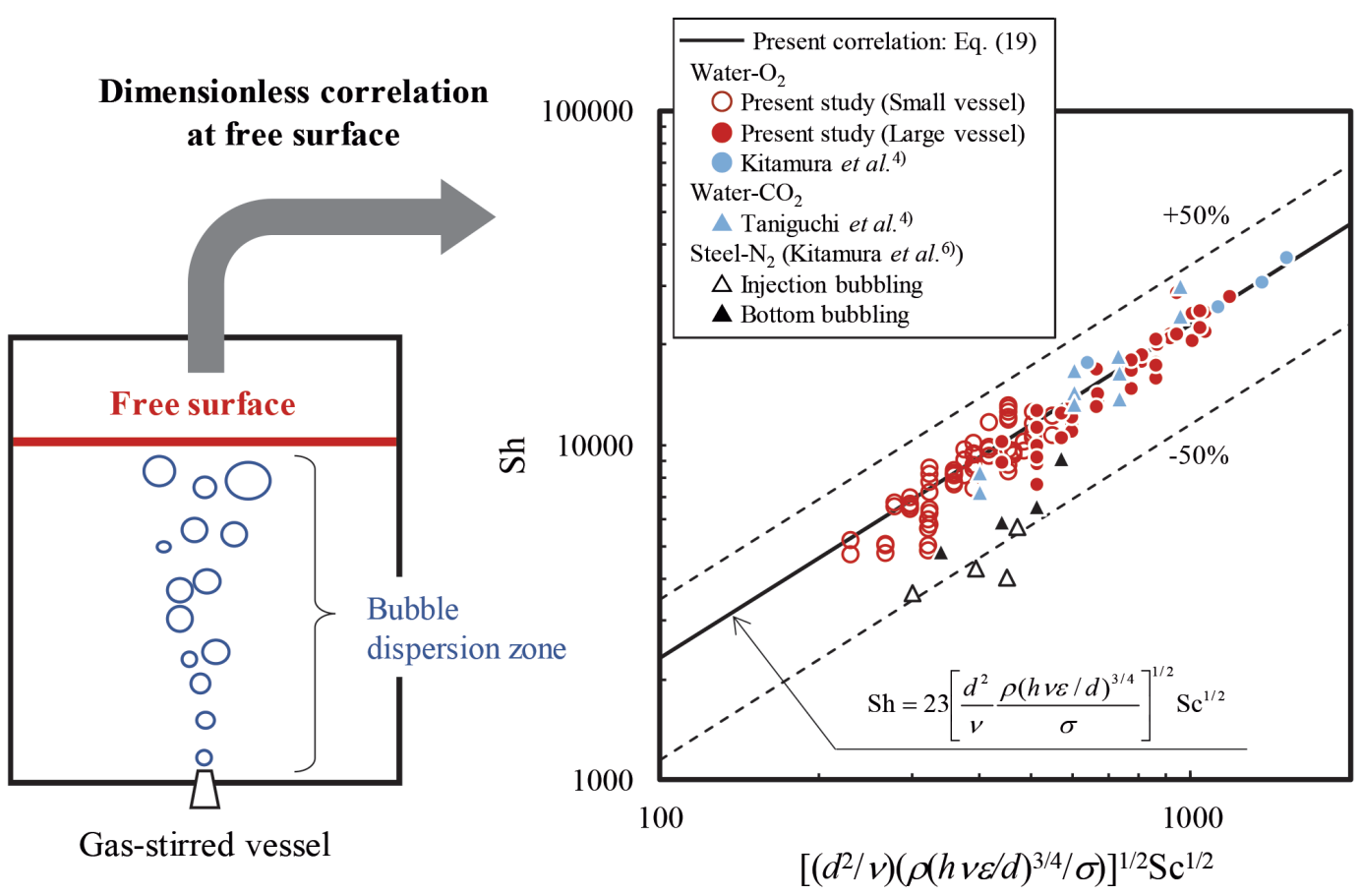

Received on Mar. 17, 2020 ; Accepted on Apr. 20, 2020

* Corresponding author. E-mail : arai-c@hachinohe.kosen-ac.jp, Address : National Institute of Technology, Hachinohe College, 16-1 Uwanotai Tamonoki-Aza Hachinohe Aomori 039-1192 


\title{
ガス攪拌槽における気液自由界面の液側物質移動の解析
}

\author{
新井 宏忠 ${ }^{1) *} \cdot$ 松本 克才 ${ }^{1)}$ \\ Analysis of Liquid Phase Mass Transfer at Free Surface in Gas-stirred Vessel \\ Hirotada Arai and Katsutoshi Matsumoto
}

\section{1. 緒言}

鉄鋼精鍊プロセスの効率化にあたり，攪挥操作は重要な 役割を果たしている。攪拌の主な役割として溶鋼温度と合 金成分の均一化の促進・迅速化, 介在物・溶存ガスの除去 促進などが挙げられ, その用途に応じて機械覮拌, ガス覮 拌, 電磁攪拌などが使い分けられる。この中で, ガス攪拌 は簡便であり，精錬プロセスで広く用いられている。

ガス攪拌によって物質移動が促進され反応の迅速化が 図れるため, ガス攪拌の機能やメカニズムが詳細に検討さ れ, 高効率化が追求されてきた。例えば, 吹込みガスの挙 動, 介在物の浮上分離, 溶存ガスの物質移動など多方面で 研究がなされている。本研究ではこれらの中で自由表面の 気液間物質移動に着目した。

2次精錬では脱水素, 加窒・脱窒処理が行われるが，こ れらの反応では気液界面を通して物質が移動する。その ため, 気液界面の物質移動特性に関する研究が古くから行 われている ${ }^{1-10)}$ 。大まかには, 律速段階に関する研究 ${ }^{1,2,10)}$, 攪拌動力や装置形状の影響 ${ }^{5,6,8)}$, 気泡域や自由表面域にお ける物質移動解析 ${ }^{3,4,69)}$ などに分けられる。本研究で扱う 気液自由界面の物質移動に限れば, Taniguchi ら ${ }^{4)}$ はガス 覮拌における気液界面を気泡分散域と自由表面域にわけ, それぞれについて物質移動モデルとの比較を行っている。 Kitamura ら ${ }^{6)}$ も同様に，それぞれの領域について物質移動 特性を評価している。Maruoka ${ }^{11,12)}$ は，スラグ層に覆わ れた気液自由界面の物質移動を対象に, プルームアイ領域 の物質移動特性を評価している。最近では, Okayama and Higuchi $^{13)}$ は数值流体解析によって気液界面積を求め, 気泡 分散域と自由表面域それぞれの物質移動係数と撌找強度 の関係を整理している。しかしながら, 水モデル系と溶鋼 系との差異や容器サイズの影響を体系的に整理する試みは 少なく，それぞれの実験系における相関式が提案されてい る $^{4,6,13)}$ 。

そこで本研究では, 気液自由界面の物質移動係数を溶存
酸素の脱ガス水モデル実験にて調査するとともに, 無次元 相関式として整理することを試みた。また，本相関式を既 往の水モデルおよび溶鋼系の実験データと比較した。

\section{2. 実験}

\section{$2 \cdot 1$ 実験装置および方法}

実験装置の概略図を Fig.1に示す。実験装置には，大き さの異なる2種類のアクリル製円筒容器を用い, 容器底部 中心にガス吹込みノズルを設置した。小容器 (容器内径 $194 \mathrm{~mm}$ ) では, 銅製単管ノズル (外径 $2 \mathrm{~mm}$, 内径 $0.8 \mathrm{~mm}$ ) から Arガスを吹込み, 大容器 (容器内径 $292 \mathrm{~mm}$ ) ではステ ンレス製単管ノズル (外径 $2.5 \mathrm{~mm}$, 内径 $2.0 \mathrm{~mm}$ ) から $\mathrm{N}_{2}$ ガ スを吹き込んだ。アクリル円筒容器を角型ガラス容器に入 れ, ヒーターおよび温度調整器にて容器内の水温を一定に 保った。また, 本実験では容器上部空間の䨌囲気に $\mathrm{O}_{2}-\mathrm{N}_{2}$

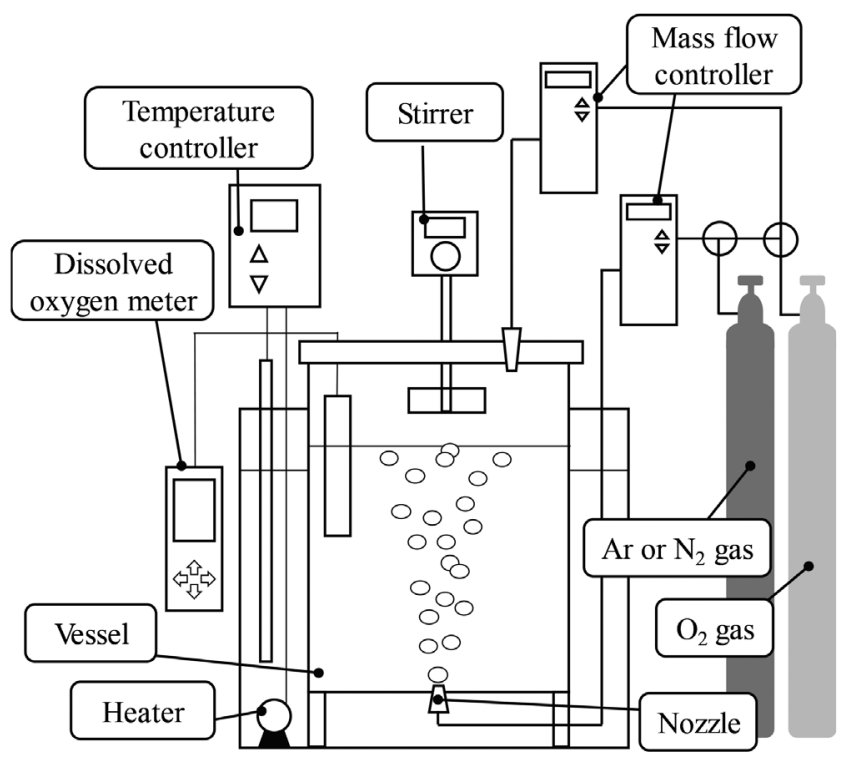

Fig. 1. Schematic diagram of experimental apparatus. 
もしくは $\mathrm{O}_{2}-\mathrm{Ar}$ 混合ガスを用いる条件もあることから, 容 器上部空間に攪拌翼を取り付け, 空間内のガス組成を均一 化した。

実験方法はまず，円筒容器に水道水を所定の高さまで満 たし， $298 \mathrm{~K}$ に保った。溶存酸素濃度が $20 \mathrm{mg} \mathrm{L}^{-1}$ になるま でノズルから $\mathrm{O}_{2}$ ガスを吹き込み，その後，ノズルからの吹 込みガスを $\mathrm{Ar}$ しくは $\mathrm{N}_{2}$ に切り替えて溶存酸素の脱ガス を開始した。溶存酸素濃度が $16 \sim 17 \mathrm{mg} \mathrm{L}^{-1}$ になった時点 から 30 秒間隔で水中の溶存酸素濃度を測定した。なお, 水 中の溶存酸素濃度は溶存酸素濃度計（HORIBA，OM-71）を 用いて測定した。

本研究では, $2 \cdot 2$ 節で述べる手法で気泡分散域と自由表 面域の容量係数を分離する。そのため，上部空間に $\mathrm{O}_{2}$ ガス を供給し，混合ガス䨌囲気 $\left(50\right.$ vol.\%- $\left.\mathrm{O}_{2}\right)$ で同様の実験を 行った。実験条件はTable 1にまとめて示す。

\section{$2 \cdot 2$ 解析方法}

ガス吹き込みでは, 溶存ガスの物質移動は気泡および自 由表面の気液界面で生じる。このとき，2つの領域全体を 含めて脱ガス速度は次式で与えられる。

$$
\frac{\mathrm{d} C}{\mathrm{~d} t}=-\frac{k_{L} A}{V}\left(C-C_{e}\right)
$$

ここで $C_{e}$ は䨌囲気ガスと平衡する水中の平衡酸素濃度で ある。全容量係数 $k_{L} A$ は気泡分散域と自由表面域の和で与 えられる。

$$
k_{L} A=\left(k_{L} A\right)_{S}+\left(k_{L} A\right)_{B}
$$

下付きの $S$ と Bはそれぞれ自由表面域と気泡分散域を示 す。

本研究では自由表面における物質移動に着目するため, 自由表面域と気泡分散域の容量係数を分離する必要があ る。そこで式 (2) を用いて式 (1) を変形すると

Table 1. Experimental conditions.

\begin{tabular}{l|c|c}
\hline \multirow{2}{*}{} & \multicolumn{2}{|c}{ Vessel } \\
\cline { 2 - 3 } & Small & Large \\
\hline Injection gas & \multicolumn{2}{|c}{298} \\
\hline Liquid temperature $(\mathrm{K})$ & \multicolumn{2}{|c}{$0.894 \times 10^{-3}$} \\
\hline Viscosity $(\mathrm{Pa} \mathrm{s})$ & \multicolumn{2}{|c}{997} \\
\hline Liquid density $\left(\mathrm{kg} \mathrm{m}^{-3}\right)$ & \multicolumn{2}{|c}{0.072} \\
\hline Surface tension $\left(\mathrm{N} \mathrm{m}^{-1}\right)$ & \multicolumn{2}{|c}{$16 \sim 17$} \\
\hline Initial oxygen conc. $\left(\mathrm{mg} \mathrm{L}^{-1}\right)$ & 194 & 292 \\
\hline Diameter of vessel $(\mathrm{mm})$ & $100,150,200,250$ & $200,300,400$ \\
\hline Liquid height $(\mathrm{mm})$ & $10.0 \sim 41.7$ & $33.3 \sim 233$ \\
\hline Gas flow rate $\left(\times 10^{-6} \mathrm{~m}^{3} \mathrm{~s}^{-1}\right)$ & 2.0 & 2.5 \\
\hline Outer diameter of nozzle $(\mathrm{mm})$ & \multicolumn{2}{|c}{ Center } \\
\hline Nozzle position & \multicolumn{2}{|c}{} \\
\hline
\end{tabular}

$\uparrow 298 \mathrm{~K}, 101325 \mathrm{~Pa}$

$$
\frac{\mathrm{d} C}{\mathrm{~d} t}=-\frac{\left(k_{L} A\right)_{B}}{V}\left(C-C_{e, B}\right)-\frac{\left(k_{L} A\right)_{S}}{V}\left(C-C_{e, S}\right) .
$$

となる。 $C_{e, B}$ と $C_{e, S}$ は，それぞれ気泡内ガスおよび雲囲気ガ スと平衡する気液自由界面における溶存酸素濃度であり, ヘンリーの法則に従うとする。ここでTaniguchi $~^{4}{ }^{4)}$ の解析 方法と同様に, $\beta$ を次式で定義する。

$$
\beta=\frac{\left(k_{L} A\right)_{S}}{k_{L} A}
$$

本実験では吹込みガスに不活性ガスを用いるため, $C_{e, B}=0$ として式（3）を整理すると

$$
\frac{\mathrm{d} C}{\mathrm{~d} t}=\frac{k_{L} A}{V}\left[-(1-\beta) C+\beta\left(C_{e, S}-C\right)\right] .
$$

となる。式 (5) を積分すると次式が得られる。

$$
\frac{C}{C_{0}}=\frac{\beta C_{e, S}}{C_{0}}+\left(1-\frac{\beta C_{e, S}}{C_{0}}\right) \exp \left(-\frac{k_{L} A}{V} t\right) .
$$

式（6）において， $C_{e, S}=0$, すなわち不活性ガス䨌囲気中 では

$$
\frac{C}{C_{0}}=\exp \left(-\frac{k_{L} A}{V} t\right) .
$$

となるので, 溶存酸素濃度の経時変化から $k_{L} A$ を求めるこ とができる。次いで同条件に打いて，上部空間の雲囲気を 50 vol.\%- $\mathrm{O}_{2}$ に変更し, 同様に溶存酸素濃度の経時変化を測 定する。式 (6) の $k_{L} A$ は既知となっているので, 式 (6) の 計算值と実測值が合うようにフィッティングし, $\beta$ を決定 する。最後に式 $(4)$ から $\left(k_{L} A\right)_{S}$ を算出し, 自由表面域のみ の容量係数を得る。

本実験条件範囲内では, 気泡プルーム部で液面の盛り上 がりが見られるものの, 全般に液面大変形はなかったた め, 自由表面の物質移動係数は単純に容器断面積で容量係 数を除して算出した。

\section{3. 結果と考察}

\section{$3 \cdot 1$ 容量係数とガス流量・液深の関係}

Fig.2に不活性ガス䨌囲気ならびに 50 vol.\%- $\mathrm{O}_{2}$ 䨌囲気で 測定した溶存酸素濃度の経時変化と式 (6) の計算值を示す。 図より, 溶存酸素濃度の経時変化を式 (6) および式 (7) で よく表せていることがわかる。

Fig.3 およびFig.4には，全容量係数，気泡分散域のおよ び自由界面の容量係数のガス流量依存性, 液深依存性を示 す。Fig.3より, ガス流量の増加にともない全容量係数が増 加しているが，これは気泡分散域の容量係数の寄与が大き い。本実験条件において，低流量では気泡分散域と自由表 
面の容量係数はほぼ同等であるが, 大流量域では気泡分散 域の容量係数が主となる。Fig.4から，いずれの容量係数も 液深が深くなるほど容量係数が増加しているが, 気泡分散

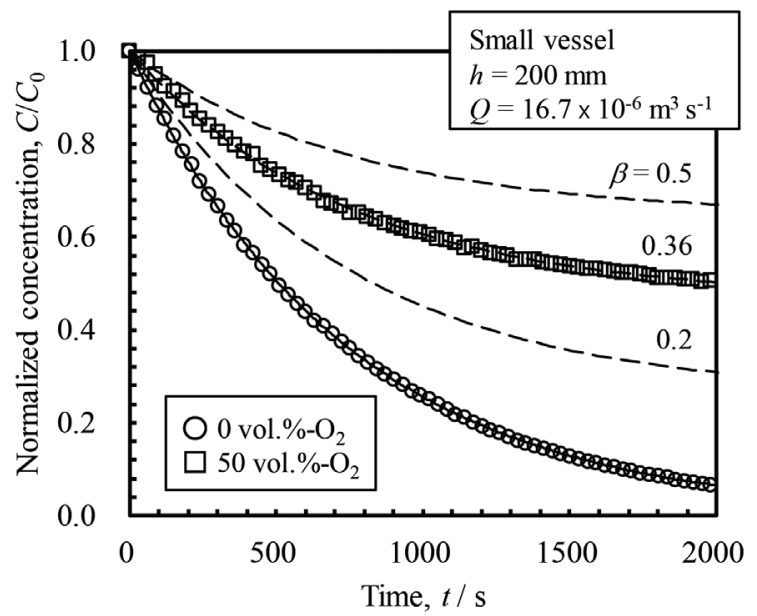

Fig. 2. Concentration-time curves for 0 vol. $\%-\mathrm{O}_{2}$ and 50 vol. $\%-\mathrm{O}_{2}$



(a) Small vessel $(d=194 \mathrm{~mm})$

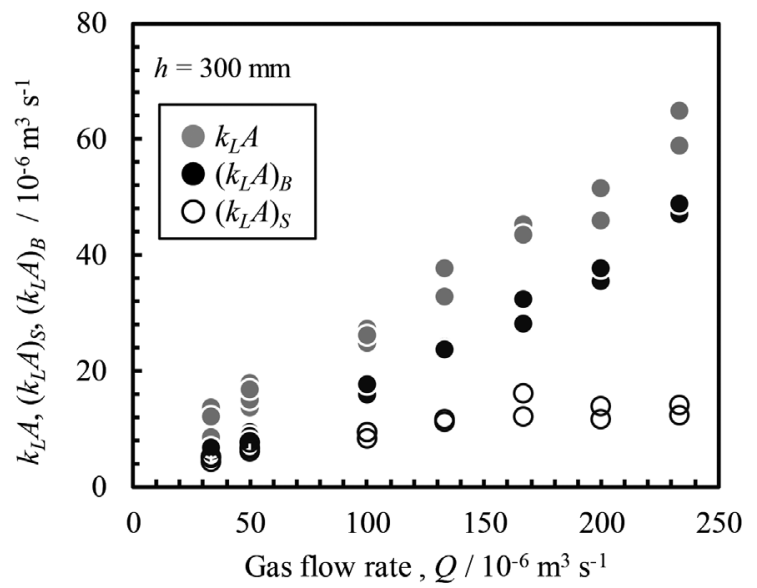

(b) Large vessel $(d=292 \mathrm{~mm})$

Fig. 3. Liquid phase volumetric coefficient as a function of gas flow rate.
域の方が増加割合が大きい。これは液深が深くなること で, 単純に気泡と液の接触界面積が増加したためと考えら れる。

\section{$3 \cdot 2$ 気液自由界面の物質移動係数に関する無次元相関式}

気液自由界面における相関式について種々報告されてい るが, Taniguchi ら ${ }^{4)}$ の相関式は次式で表される。

$$
\left(k_{L} A\right)_{S}=138 D^{0.5} Q^{0.5} r
$$

この相関式と本実験データを比較した図が Fig.5である。 概ね Taniguchi らの相関式で表せているが, 液深が浅い条件 では相関式と実験值との差異が大きくなる傾向にある。こ れは, 式 (8) に液深依存性が含まれていないためと考える。

一方，気液自由界面の物質移動モデルについても，乱 流渦による輸送モデルがいくつか提案されており ${ }^{14,15)}$, Taniguchiらはガス攪拌槽における自由表面の物質移動係 数の測定値と比較したものの, 渦モデルでは実験值を説明 できないことを報告している ${ }^{16)}$

固体表面と異なり自由界面は変形できるので, この考察 を行う上では気液間の密度差や表面張力などの因子も考慮

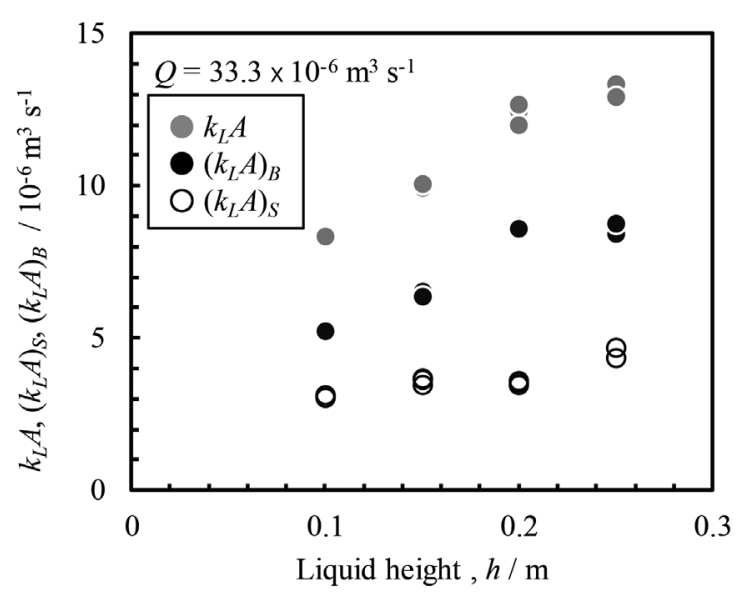

(a) Small vessel $(d=194 \mathrm{~mm})$

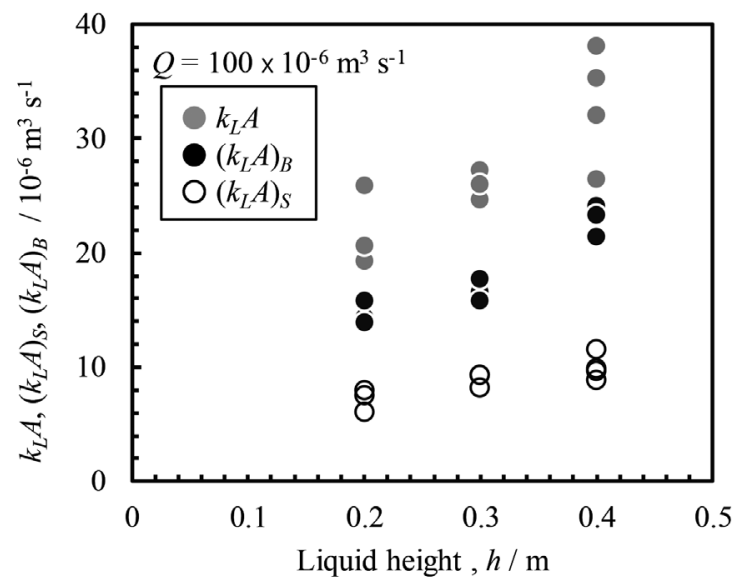

(b) Large vessel $(d=292 \mathrm{~mm})$

Fig. 4. Liquid phase volumetric coefficient as a function of liquid height. 
する必要があると推察される。Levich ${ }^{17)}$ は十分に発達した 乱流状態で平板上を流れる液膜表面からのガス吸収を解析 するために，表面張力によって表面近傍で乱流が減衰する モデルを提案した。Levichは, 気液界面で乱流は減衰して 表面まで到達しないとしたが, Davies ${ }^{18)}$ は覮拌槽液面の観 察から表面更新が起こるとしてLevichの理論を拡張して いる。

Kataoka and Miyauchi ${ }^{19)}$ は乱流域の機械式攪拌槽自由表 面のガス吸収実験を行い，ガス吸収速度はLevichの理論で 説明できることを示している。溶銅ースラグ系（液液系） ではあるが, Hirasawa ${ }^{20)}$ はDaviesの理論をもとに無次元 相関式を導出し，種々の実験データを統一的に整理した。 そこで, Levichの物質移動モデルをもとに, 本研究でも同 様に無次元相関式を構築した。

Levichの理論は次式で表される。

$$
k_{L, S} \propto\left(\frac{D \rho v_{0}^{3}}{\sigma}\right)^{1 / 2}
$$

ここで変動速度 $v_{0}$ は Kolmogorov スケールの渦の代表速度 に等しいと仮定する*。Kolmogorovの最小渦は等方性乱流 場によるものであり，界面近傍の乱流場とは異なると考え られるが, 単純化のためにKolmogorov スケールの渦速度 で代表させ，次式で与える。

$$
v_{0} \equiv\left(v \epsilon_{s}\right)^{1 / 4}
$$

$\varepsilon_{S}$ は自由表面近傍の乱流エネルギー消散速度であり, 覮 找槽内に打ける $\varepsilon$ 分布の不均一性から槽内の平均乱流エネ

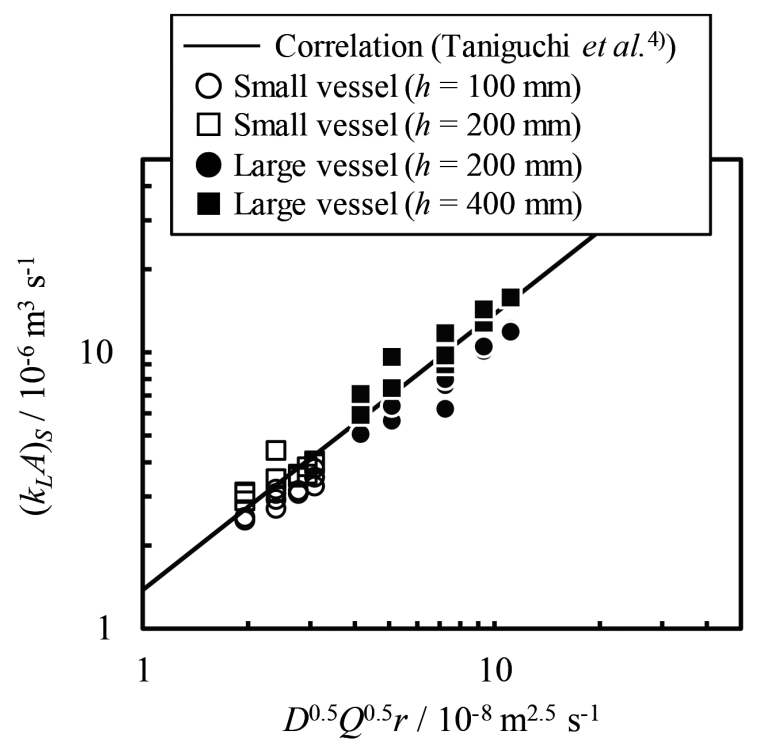

Fig. 5. Comparison of liquid phase volumetric coefficient at free surface between previous study ${ }^{4}$ and present data.
ルギー消散速度 $\varepsilon$ (摚拌動力密度) とは区別する。また, 後 述のように摼拌動力密度と関係づけることができ, 実用的 に扱いやすくなる。

式（9）および式（10）を用いて無次元相関式に整理する と

$$
\mathrm{Sh}=C_{1}\left[\frac{d^{2}}{v} \frac{\rho\left(v \epsilon_{s}\right)^{3 / 4}}{\sigma}\right]^{1 / 2} \mathrm{Sc}^{1 / 2} .
$$

となる。 $C_{1}$ は比例定数である。

一般に, 乱流エネルギー消散速度はガス擤拌槽内で分布 を持ち, 気泡上昇域に集中している。また, 上昇流は表面 近傍で表面流を形成し，ここでもエネルギー消散が生じ る。したがって，エネルギー消散は槽内で局所的に生じて おり, 槽内平均値を用いることは不適当である。そこで, Hirasawa ${ }^{20)}$ と同様に, Fig.6に示すように自由界面から厚 さ $h_{s}$ の距離まで乱流が強い領域があると仮定し, 系に投入 されたエネルギーの一部が自由表面近傍の領域で局所的に 消散されると考えた。

槽内の平均乱流エネルギー消散速度は, 覮找動力密度と 等価であるので,

$$
\begin{aligned}
& \epsilon=\frac{P Q}{M} \ln \left(1+\frac{\rho g h}{P}\right) \ldots . \\
& M=\frac{\pi d^{2} h \rho}{4}
\end{aligned}
$$

で与えられる22)。仮定より，攂拌槽内に投入されたエネル ギーが自由表面からの深さ $h_{s}$ 内で消費される割合を $\alpha$ とす れば

$$
\epsilon_{s}=\alpha \frac{P Q}{M^{\prime}} \ln \left(1+\frac{\rho g h}{P}\right)=\alpha \frac{M}{M^{\prime}} \epsilon
$$

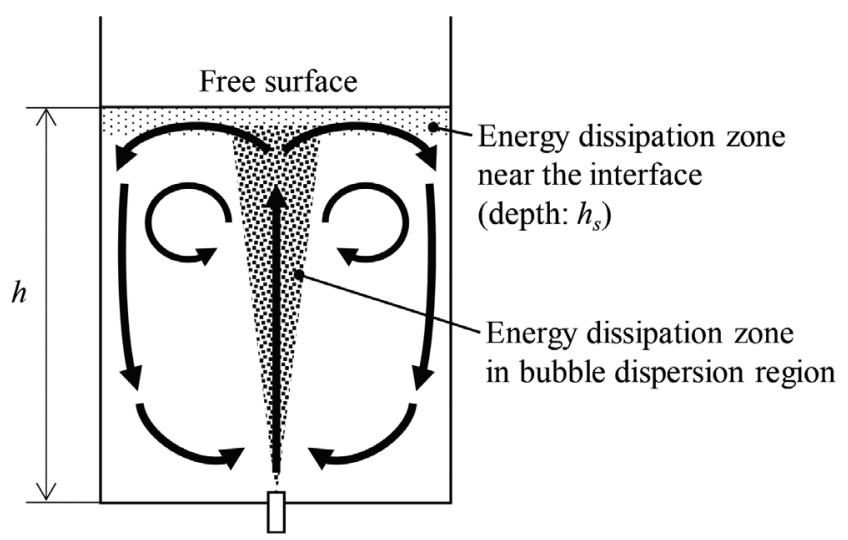

Fig. 6. Schematic representation of energy dissipation zones in gas-stirred vessel

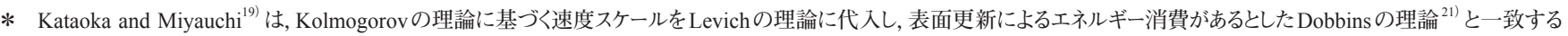
ことを示した。Levichの理論では表面更新を考えていないが, 表面更新の立場から解釈可能であるとしているので, 本研究ではLevichの理論を用いた。 


$$
M^{\prime}=\frac{\pi d^{2} h_{s} \rho}{4}
$$

と表される。

次に, $h_{s}$ を見積もるため, Fig.7に示すように液面に到達 した気泡噴流から分かれた流体が自由表面に沿って流れ， 境界層が生じると考える。境界層の厚みは固体壁面への円 形衝突噴流では半径方向の距離に比例することから ${ }^{23)}$, 本 研究のような自由界面においてもこの関係が成り立つとし $\tau$

$$
l \propto L
$$

と表せる。 $L$ を $d$ で代表し, そのときの境界層の厚みが $h_{s} に$ 相当すると考えれば

$$
h_{s}=\gamma d \text {. }
$$

と与えられ, $h_{s}$ を $d$ 関係付けられる。厳密には液面半径 方向で $h_{s}$ は変化するが, 本報ではオーダーのみに着目し, 容器直径オーダーの位置の境界層厚みで $h_{s}$ を代表させる。 式（13）〜（15），(17）を整理すると

$$
\epsilon_{s}=\frac{\alpha}{\gamma} \frac{h}{d} \epsilon
$$

となり，式（11）に代入すれば, 最終的に次式の気液自由界 面の物質移動係数に関する無次元相関式が得られる。

$$
\begin{aligned}
\mathrm{Sh} & =C_{1}\left(\frac{\alpha}{\gamma}\right)^{3 / 8}\left[\frac{d^{2}}{v} \frac{\rho(h v \epsilon / d)^{3 / 4}}{\sigma}\right]^{1 / 2} \mathrm{Sc}^{1 / 2} \\
& =C_{2}\left[\frac{d^{2}}{v} \frac{\rho(h v \epsilon / d)^{3 / 4}}{\sigma}\right]^{1 / 2} \mathrm{Sc}^{1 / 2}
\end{aligned}
$$

Fig.8に本実験データを式（19）によって整理した結果を 示す。 $\mathrm{O}_{2}$ の拡散係数はWilke and Changの推算式 ${ }^{24)}$ より求

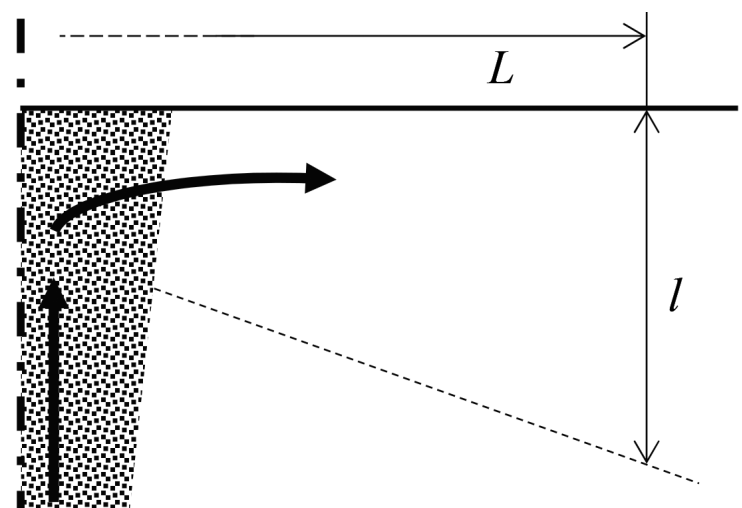

\section{Bubble plume}

Fig. 7. Schematic representation of liquid flow near the free surface.
めた。図より，実験結果は式 $(19)\left(C_{2}=23\right)$ でよく整理さ れていることがわかる。

次に, ガス流量および液深が自由表面の物質移動係数に

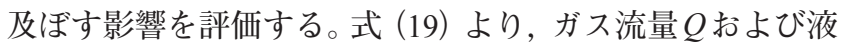
深 $h$ の依存性は，それぞれ以下のように与えられる。

$$
\begin{aligned}
& k_{L, S} \propto Q^{0.375} \ldots \ldots \ldots \ldots \ldots \ldots . \ldots . \ldots . . . \\
& k_{L, S} \propto h^{0.375} \quad(P \gg \rho g h) .
\end{aligned}
$$

Fig.9に, $k_{L, S}$ のガス流量依存性を示す。実験誤差により 依存性に幅があるが, 本実験条件において, $k_{L, S}$ はガス流量 の0.3 0.7 乗の依存性を示した。Taniguchi $ら^{4)}$ P Kitamura $ら^{6)}$ は, 自由表面の容量係数はガス流量の 0.5 乗に比例す ると報告しており，本実験結果の範囲にある。Fig.10には $k_{L, S}$ の液深依存性を示すが, $k_{L, S}$ は液深の $0.2 \sim 0.5$ 乗の依存 性を示した。Fig.9 と Fig.10には相関式から求めた $k_{L, S}$ も示 したが，それぞれ本実験結果の依存性とほぼ一致してい る。

\section{$3 \cdot 3$ 既往の研究との比較}

Fig.8には, Taniguchi $ら^{4)}$ と Kitamura $ら^{6)}$ の実験データを 合わせて示したが，実験系やガス吹込み方式の違いによら ず, 水モデル系は式(19)によって整理できている。ただし, Kitamura $5^{6)}$ の溶鋼系の実験データは本相関式の傾向と一 致しているものの, 本相関式は打よそ50\%程度大きく見積 もっている。Kitamura $ら^{6)}$ の溶鋼系のデータは, 本実験条 件と同様にスラグ無しの大気圧下で行われたものを用いた が, 界面反応抵抗によって見掛け上, 物質移動係数が低下 している可能性がある。

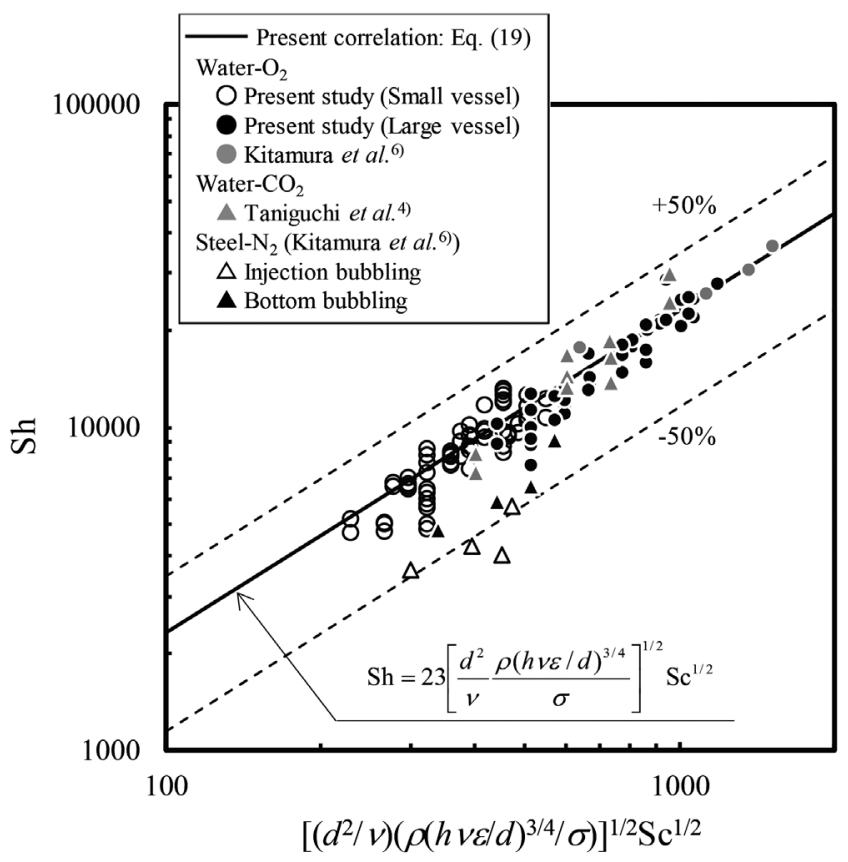

Fig. 8. Dimensionless correlation of liquid phase mass transfer coefficient at free surface for a gas-liquid system. 
また, 液面変形や表面波動の影響が挙げられる。Table 2 に, 種々の系に打ける物性値ならびにエトべス数を示し た。水系において，エトべス数は概ね $10^{4}$ オーダーであり， 溶鋼系では $10^{3}$ オーダーである。水系では溶鋼系と比較し て表面張力の影響が小さく，液面変形しやすいといえる。 本実験では気液自由界面の物質移動係数を求める際, 気液 自由界面は容器断面積に等しいとした。この場合, 液面変 形が生じると物質移動係数を過大に見積もることになる。 溶鋼系との差異を埋めるには, 自由界面積が容器断面積の 2 倍程度になる必要があるが, 本実験条件では液面の盛り 上がりは数 $\mathrm{cm}$ 程度であり,これだけでは説明できない。

Taniguchi ${ }^{16)}$ は, 自由表面の波動 (乱流による不規則波) の生成に䚇挥動力の一部が消費されるとし，系に投入され たエネルギーのかなりの割合が表面波動に費やされている と指摘している。爷の結果, 系に投入された覞拌動力が物 質移動に寄与する割合が小さくなると考えられる。この割 合が水モデル系と溶鋼系で異なるため, 差異が生じた可能 性がある。今後, 液面変形や表面波動など, 物質移動に影

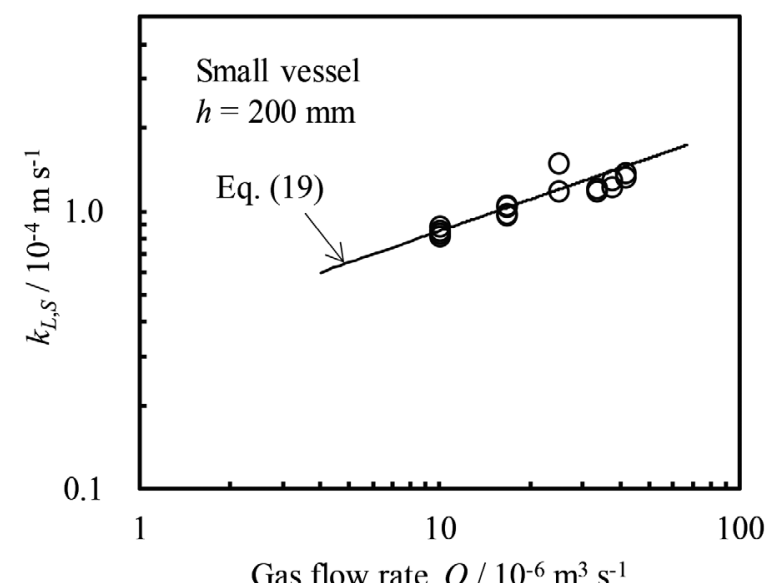

(a) Small vessel $(d=194 \mathrm{~mm})$

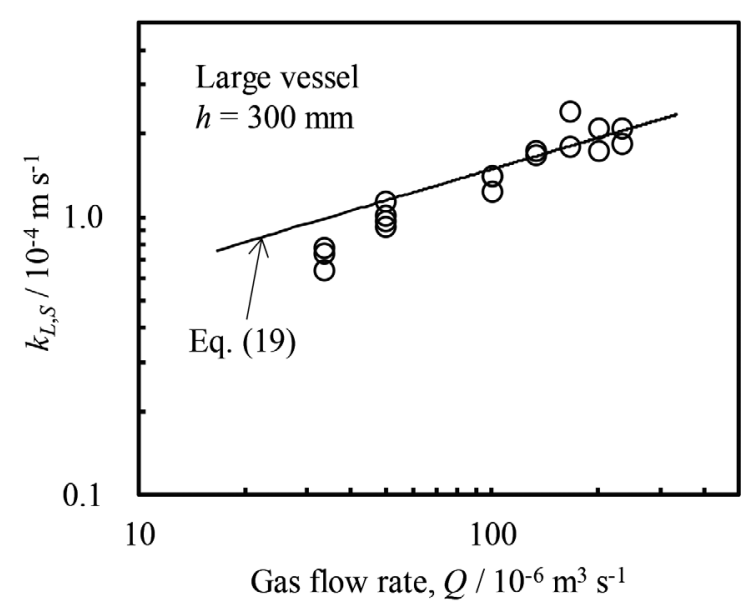

(b) Large vessel $(d=292 \mathrm{~mm})$

Fig. 9. Liquid phase mass transfer coefficient at free surface as a function of gas flow rate.
響する因子について更なる調査が必要である。

\section{4. 結言}

本報では, 水モデル実験により気液自由界面における物 質移動解析を行った。考察に打いては, Levichの物質移動 モデルをべースに, 気液自由界面の流動状態を考慮して以 下の無次元相関式を構築した。

Table 2. Property values for various gas-liquid systems.

\begin{tabular}{|c|c|c|c|c|c|}
\hline \multirow{2}{*}{ Property } & \multirow{2}{*}{$\begin{array}{c}\begin{array}{c}\text { Present } \\
\text { study }\end{array} \\
\text { Water-O }\end{array}$} & \multicolumn{2}{|c|}{ Taniguchi et al. ${ }^{4)}$} & \multicolumn{2}{|c|}{ Kitamura et al. ${ }^{6}$} \\
\hline & & Water- $\mathrm{O}_{2}$ & Water- $\mathrm{CO}_{2}$ & Water- $\mathrm{O}_{2}$ & Steel-N \\
\hline$\rho_{g}\left(\mathrm{~kg} \mathrm{~m}^{-3}\right)$ & 1.3 & 1.3 & 1.8 & 1.3 & 1.1 \\
\hline$\rho\left(\mathrm{kg} \mathrm{m}^{-3}\right)$ & 997 & 997 & 997 & 997 & 7000 \\
\hline$\Delta \rho\left(\mathrm{kg} \mathrm{m}^{-3}\right)$ & 996 & 996 & 995 & 996 & 6999 \\
\hline$\sigma\left(\mathrm{N} \mathrm{m}^{-1}\right)$ & 0.072 & 0.072 & 0.072 & 0.072 & 1.8 \\
\hline$d(\mathrm{~m})$ & 0.194 & 0.292 & 0.29 & 0.3 & 0.25 \\
\hline Eo $\left(\times 10^{3}\right)$ & 5.1 & 12 & 11 & 12 & 2.4 \\
\hline
\end{tabular}

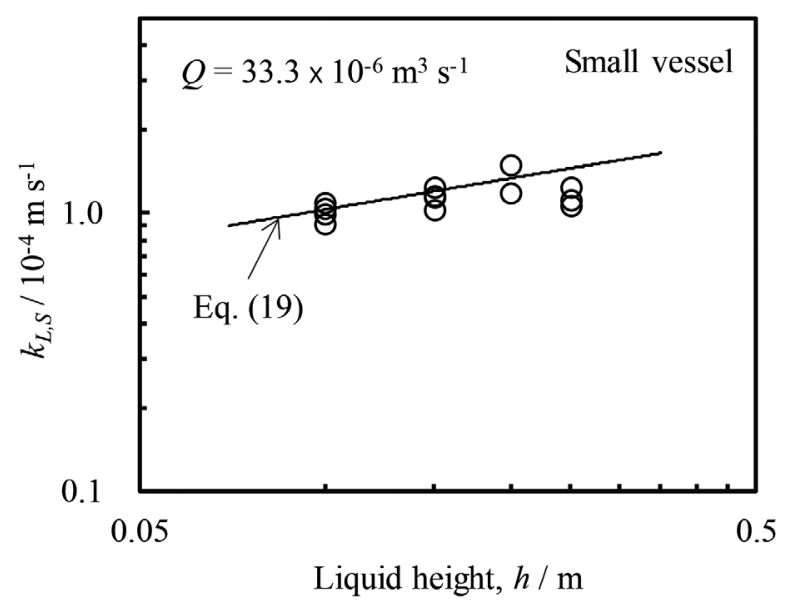

(a) Small vessel $(d=194 \mathrm{~mm})$

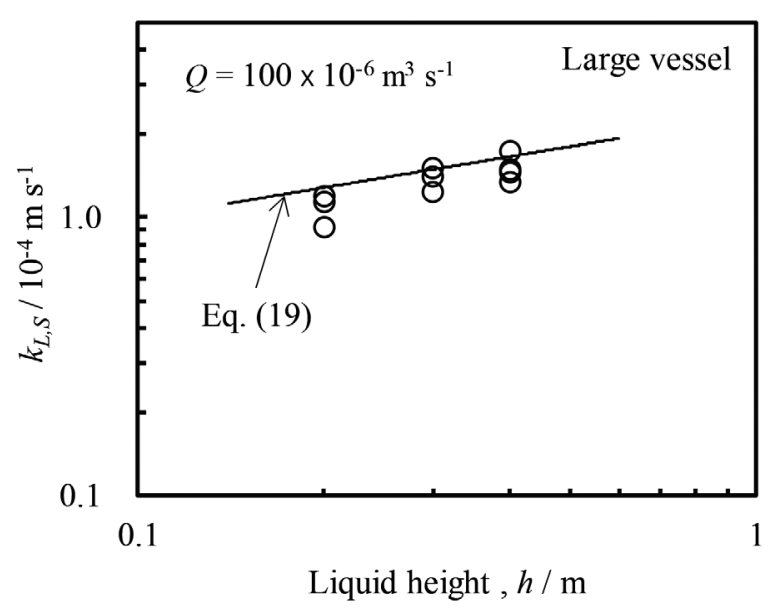

(b) Large vessel $(d=292 \mathrm{~mm})$

Fig. 10. Liquid phase mass transfer coefficient at free surface as a function of liquid height. 


$$
\mathrm{Sh}=23\left[\frac{d^{2}}{v} \frac{\rho(h v \epsilon / d)^{3 / 4}}{\sigma}\right]^{1 / 2} \mathrm{Sc}^{1 / 2}
$$

上式は，本実験データならびに既往の水モデル実験デー タも統一的にまとめることができた。一方，溶鋼系の実験 データに対し, 本相関式は $50 \%$ 程度物質移動係数を大きく 見積もったが，大略傾向を表すことができた。

\section{謝辞}

本研究は, 第26回鉄鋼研究振興助成の支援を受けて実施 されたものであることを記して謝意を表する。

\section{使用記号}

\begin{tabular}{|c|c|}
\hline$A\left(\mathrm{~m}^{2}\right)$ & 自由表面積 (=容器断面積) \\
\hline$C\left(\mathrm{~mol} \mathrm{~m}^{-3}\right)$ & 溶存酸素濃度 \\
\hline$C_{1}, C_{2}(-)$ & 比例定数 \\
\hline$D\left(\mathrm{~m}^{2} \mathrm{~s}^{-1}\right)$ & 分子拡散係数 \\
\hline$d(\mathrm{~m})$ & 容器直径 \\
\hline Eo $(-)$ & エトベス数 $\left(=\Delta \rho g d^{2} / \sigma\right)$ \\
\hline$g\left(\mathrm{~m} \mathrm{~s}^{-2}\right)$ & 重力加速度 \\
\hline$h(\mathrm{~m})$ & 液深 \\
\hline$h_{s}(\mathrm{~m})$ & 乱流が強い領域の厚み \\
\hline$k_{L}\left(\mathrm{~m} \mathrm{~s}^{-1}\right)$ & 物質移動係数 \\
\hline$k_{L} A\left(\mathrm{~m}^{3} \mathrm{~s}^{-1}\right)$ & 気液界面の容量係数 \\
\hline$L(\mathrm{~m})$ & 代表長さ \\
\hline$l(\mathrm{~m})$ & 乱流境界層の厚さ \\
\hline$M(\mathrm{~kg})$ & 液質量 \\
\hline$M^{\prime}(\mathrm{kg})$ & 自由表面近傍の液質量 $\left(=\pi d^{2} h_{s} \rho / 4\right)$ \\
\hline$P(\mathrm{~Pa})$ & 雲囲気圧力 \\
\hline$Q\left(\mathrm{~m}^{3} \mathrm{~s}^{-1}\right)$ & ガス流量 $(298 \mathrm{~K}, 101325 \mathrm{~Pa})$ \\
\hline$r(\mathrm{~m})$ & 容器半径 \\
\hline $\operatorname{Sc}(-)$ & シュミット数 $(=v / D)$ \\
\hline Sh $(-)$ & シャーウッド数 $\left(=k_{L} d / D\right)$ \\
\hline$t(\mathrm{~s})$ & 時間 \\
\hline$V\left(\mathrm{~m}^{3}\right)$ & 液体積 \\
\hline$v_{0}\left(\mathrm{~m} \mathrm{~s}^{-1}\right)$ & Kolmogorov スケールの渦の代表速度 \\
\hline$\alpha(-)$ & 自由表面近傍で消費されるエネルギーの割合 \\
\hline$\beta(-)$ & $\left(k_{L} A\right)_{S} / k_{L} A$ \\
\hline$\gamma(-)$ & 比例定数 \\
\hline$\varepsilon\left(\mathrm{m}^{2} \mathrm{~s}^{-3}\right)$ & 槽内の平均乱流エネルギー消散速度 (㩖拌動力密度) \\
\hline$\varepsilon_{S}\left(\mathrm{~m}^{2} \mathrm{~s}^{-3}\right)$ & 自由表面近傍の乱流エネルギー消散速度 \\
\hline$v\left(\mathrm{~m}^{2} \mathrm{~s}^{-1}\right)$ & 液の動粘性係数 \\
\hline$\rho\left(\mathrm{kg} \mathrm{m}^{-3}\right)$ & 液密度 \\
\hline$\rho_{\mathrm{g}}\left(\mathrm{kg} \mathrm{m}^{-3}\right)$ & ガス密度 \\
\hline$\Delta \rho\left(\mathrm{kg} \mathrm{m}^{-3}\right)$ & ガスと液の密度差 $\left(=\rho-\rho_{\mathrm{g}}\right)$ \\
\hline$\sigma\left(\mathrm{N} \mathrm{m}^{-1}\right)$ & 表面張力 \\
\hline
\end{tabular}

\section{下付き記号}

$\begin{array}{ll}B & \text { 気泡分散域 } \\ S & \text { 自由表面域 } \\ e & \text { 平衡值 } \\ 0 & \text { 初期值 }\end{array}$

\section{文献}

1 ) K.Kadoguchi, M.Sano and K.Mori: Tetsu-to-Hagané, 71(1985), 70 (in Japanese). https://doi.org/10.2355/tetsutohagane1955.71.1_70

2 ) M.Kawakami, K.Ito, M.Okuyama, T.Kikuchi and S.Sakase: Tetsuto-Hagané, 73(1987), 661 (in Japanese). https://doi.org/10.2355/ tetsutohagane1955.73.6_661

3 ) S.Taniguchi, A.Kikuchi, H.Matsuzaki and N.Bessho: Trans. Iron Steel Inst. Jpn., 28(1988), 262. https://doi.org/10.2355/ isijinternational1966.28.262

4 ) S.Taniguchi, Y.Okada, A.Sakai and A.Kikuchi: Proc. 6th Int. Iron \& Steel Congr., ISIJ, Tokyo, (1990), 394.

5 ) K.Sakaguchi and K.Ito: ISIJ Int., 35(1995), 1348. https://doi. org/10.2355/isijinternational.35.1348

6 ) S.Kitamura, K.Miyamoto and R.Tsujino: Tetsu-to-Hagané, 80(1994), 101 (in Japanese). https://doi.org/10.2355/tetsutohagane1955.80.2_101

7 ) K.Miyamoto, R.Tsujino, S.Kitamura, T.Inomoto, A.Shinkai, K.Kato and T.Yuki: Tetsu-to-Hagané, 82(1996), 117 (in Japanese). https:// doi.org/10.2355/tetsutohagane1955.82.2 117

8 ) Y.Higuchi and Y.Shirota: Tetsu-to-Hagané, 86(2000), 748 (in Japanese). https://doi.org/10.2355/tetsutohagane1955.86.11_748

9 ) T.Kumagai, M.Iguchi and T.Nakatani: Tetsu-to-Hagané, 89(2003), 735 (in Japanese). https://doi.org/10.2355/tetsutohagane1955.89.7_735

10) F.Takahashi, Y.Momoi, K.Kajikawa and H.Yamada: Tetsu-toHagané, 97(2011), 525 (in Japanese). https://doi.org/10.2355/ tetsutohagane.97.525

11) N.Maruoka, F.Lazuardi, H.Nogami, G.S.Gupta and S.Kitamura: ISIJ Int., 50(2010), 89. https://doi.org/10.2355/isijinternational.50.89

12) N.Maruoka, F.Lazuardi, T.Maeyama, S.Kim, A.N.Conejo, H.Shibata and S.Kitamura: ISIJ Int., 51(2011), 236. https://doi.org/10.2355/ isijinternational.51.236

13) A.Okayama and Y.Higuchi: Tetsu-to-Hagané, 105(2019), 793 (in Japanese). https://doi.org/10.2355/tetsutohagane.TETSU-2018-160

14) G.E.Fortescue and J.R.A.Pearson: Chem. Eng. Sci., 22(1967), 1163. https://doi.org/10.1016/0009-2509(67)80183-0

15) J.C.Lamont and D.S.Scott: AIChE J., 16(1970), 513. https://doi. org/10.1002/aic.690160403

16) S.Taniguchi, Y.Matsukura and A.Kikuchi: Tetsu-to-Hagané, 86(2000), 210 (in Japanese). https://doi.org/10.2355/tetsutohagane1955.86.4_210

17) V.G.Levich: Physicochemical Hydrodynamics, Prentice Hall, Englewood Cliffs, NJ, (1962), 689.

18) J.T.Davies: Proc. R. Soc. A., 290(1966), 515. https://doi.org/10.1098/ rspa.1966.0067

19) H.Kataoka and T.Miyauchi: Kagaku Kogaku, 36(1972), 888 (in Japanese). https://doi.org/10.1252/kakoronbunshu1953.36.888

20) M.Hirasawa, K.Mori, M.Sano, Y.Shimatani and Y.Okazaki: Tetsuto-Hagané, 73(1987), 1350 (in Japanese). https://doi.org/10.2355/ tetsutohagane1955.73.10_1350

21) W.E.Dobbins: J. Sanit. Eng. Div., Proc. Am. Soc. Civ. Eng., 90(1964), 53.

22) K.Nakanishi, T.Fujii and J.Szekely: Ironmaking Steelmaking, 2(1975), 193.

23) Y.Era and A.Saima: Trans. Jpn. Soc. Mech. Eng., 41(1975), 3259 (in Japanese). https://doi.org/10.1299/kikai1938.41.3259

24) C.R.Wilke and P.Chang: AIChE J., 1(1955), 264. https://doi. org/10.1002/aic.690010222 